\title{
It is important to evaluate lymph nodes, but why count how many you got?
}

\author{
Farhood Farjah, MD, MPH
}

\author{
From the Division of Cardiothoracic Surgery, Department of Surgery, University of Washington, Seattle, Wash. \\ Disclosures: Author has nothing to disclose with regard to commercial support. \\ Received for publication April 6, 2018; accepted for publication April 9, 2018; available ahead of print May 17, \\ 2016 \\ Address for reprints: Farhood Farjah, MD, MPH, Division of Cardiothoracic Surgery, University of Washington, \\ 1959 NE Pacific St, Box 356310, Seattle, WA 98195 (E-mail: ffarjah@uw.edu). \\ J Thorac Cardiovasc Surg 2018;156:378-9 \\ $0022-5223 / \$ 36.00$ \\ Copyright $($ C 2018 by The American Association for Thoracic Surgery \\ https://doi.org/10.1016/j.jtcvs.2018.04.039
}

Patients potentially eligible for participation in the Lung Cancer Study Group trial underwent lymph node sampling with frozen-section analysis before randomization. ${ }^{1}$ Those with negative nodes were then randomly assigned to undergo lobar versus sublobar resection, whereas patients with positive nodes were ineligible for study. Implicit in this process is the notion that accurate nodal staging is critical for surgical decision making and that patients with nodal disease should not undergo sublobar resection.

The key finding from the study of Yendamuri and colleagues $^{2}$ in this issue of the Journal is that many patients undergoing sublobar resection did not receive any lymph node evaluation - and thus many patients may have had their disease inaccurately staged, precluding optimal surgical decision making. Similar findings were recently reported by a California cancer registry study. ${ }^{3}$ These observations provide further evidence of significant gaps in the quality of lung cancer care. ${ }^{4}$ Potential remedies include interventions to minimize lymph node nonexamination rates, ${ }^{5}$ incorporation of more process measures into performance feedback reports provided by the Society of Thoracic Surgeons, ${ }^{6}$ selective referral to board-certified thoracic surgeons, ${ }^{7}$ and linking reimbursement to performance.

Yendamuri and colleagues ${ }^{2}$ also report that a higher lymph node count was associated with better survival. The nature of this relationship, however, remains unclear. The American College of Surgery Oncology Group Z0030 trial randomly assigned patients with surgically staged T1N0-1 lung cancer to undergo mediastinal lymph node dissection versus mediastinal lymph node sampling. ${ }^{8}$ Although it was not framed as such, this trial essentially tested whether "more versus fewer" lymph nodes matters. The greater number of lymph nodes in the dissection arm had no effect on long-term survival-the median number of lymph nodes removed in the dissection arm was 18 , with $99 \%$ of patients having at least 6 lymph nodes compelling.

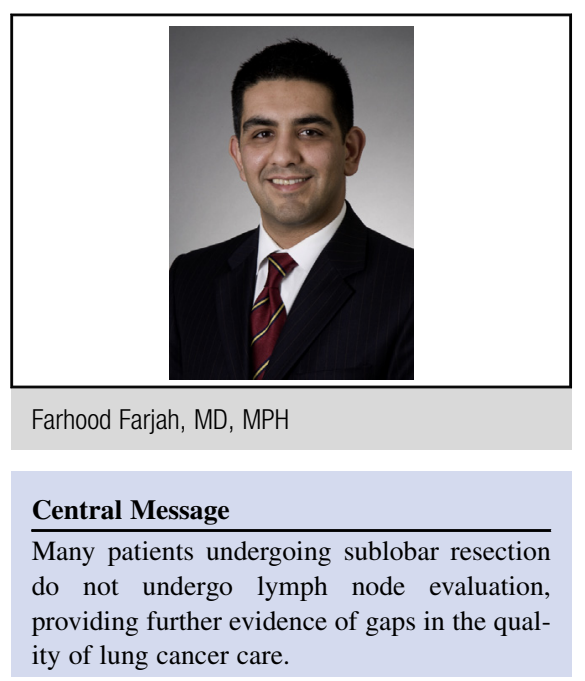

See Article page 394

removed (exact counts were not reported for the sampling arm). Given this higher level of evidence, it seems that the most likely reason for a relationship between lymph node counts and survival in an observational study is bias arising from unmeasured confounders (patient and provider characteristics) and missing data-both of which problems are rampant in large database studies.

The American College of Surgeons has endorsed removal of at least 10 lymph nodes as a quality metric in a wellintended effort to improve care. ${ }^{9}$ Thoracic surgeons have noted logistic challenges relating to valid measurement. ${ }^{10}$ Lymph node counts depend on patient biology, surgeon and pathologist behavior, and naming and counting practices (eg, fragment vs whole node). ${ }^{11}$ Regardless of whether the concern is logistic or scientific, the idea that removing more lymph nodes improves survival is not particularly

Future research should aim to help surgeons with a difficult decision that can arise from adhering to optimal nodal staging practices-specifically, what do to with a positive node on frozen section when the reason for the sublobar resection is that the patient is a high-risk lobectomy candidate. Should the surgeon abandon the operation, do a highrisk lobectomy in a patient with a worse cancer prognosis, or perform a likely futile sublobar resection? Helping patients and surgeons make these tough decisions in an era of expanded surgical options for lung cancer would be an important contribution to our field. 


\section{References}

1. Ginsberg RJ, Rubinstein LV. Randomized trial of lobectomy versus limited resection for T1 N0 non-small cell lung cancer. Lung Cancer Study Group. Ann Thorac Surg. 1995;60:615-22.

2. Yendamuri S, Dhillon SS, Groman A, Dy G, Dexter E, Picone A, et al. Impact of the number of lymph nodes examined on the survival of patients with stage I nonsmall cell lung cancer undergoing sublobar resection. J Thorac Cardiovasc Surg. 2018;156:394-402.

3. David EA, Cooke DT, Chen Y, Nijar K, Canter RJ, Cress RD. Does lymph node count influence survival in surgically resected non-small cell lung cancer? Ann Thorac Surg. 2017;103:226-35.

4. Farjah F, Detterbeck FC. What is quality, and can we define it in lung cancer?the case for quality improvement. Transl Lung Cancer Res. 2015;4:365-72.

5. Ray MA, Faris NR, Smeltzer MP, Fehnel C, Houston-Harris C, Levy P, et al. Effectiveness of implemented interventions on pathologic nodal staging of non-small cell lung cancer. Ann Thorac Surg. March 10, 2018 [Epub ahead of print].

6. Seder CW, Raymond D, Wright CD, Gaissert HA, Chang AC, Clinton S, et al. The Society of Thoracic Surgeons General Thoracic Surgery Database: 2018 update on outcomes and quality. Ann Thorac Surg. 2018;105:1304-7.

7. Farjah F, Flum DR, Varghese TK Jr, Symons RG, Wood DE. Surgeon specialty and long-term survival after pulmonary resection for lung cancer. Ann Thorac Surg. 2009;87:995-1004; discussion 1005-6.

8. Darling GE, Allen MS, Decker PA, Ballman K, Malthaner RA, Inculet RI, et al. Randomized trial of mediastinal lymph node sampling versus complete lymphadenectomy during pulmonary resection in the patient with $\mathrm{N} 0$ or $\mathrm{N} 1$ (less than hilar) non-small cell carcinoma: results of the American College of Surgery oncology group Z0030 trial. J Thorac Cardiovasc Surg. 2011; 141:662-70.

9. American College of Surgeons. CoC Quality of Care Measures: Standard 4.4 and 4.5 Expected Performance Rates, 2018 Surveys. Available at: https://www.facs org/quality-programs/cancer/ncdb/qualitymeasures. Accessed April 4, 2018.

10. Handy JR Jr, Costas K, Nisco S, Schaerf R, Vallières E, Hussain SX, et al Regarding American College of Surgeons commission on cancer non-small cell lung cancer quality of care measure 10RLN. Ann Thorac Surg. 2016;102: 1040-1.

11. Bosch DE, Farjah F, Wood DE, Schmidt RA. Regional lymph node sampling in lung carcinoma: a single institutional and national database comparison. Hum Pathol. February 12, 2018 [Epub ahead of print]. 